\title{
MODERN ACTIVE METHODS IN THE PROCESS OF FORMING STUDENTS’ ECOLOGICAL COMPETENCE
}

\section{Olha Shvets ${ }^{1}$ \\ Nataliia Osmuk ${ }^{2}$}

DOI: https://doi.org/10.30525/978-9934-588-39-6-16

Recently conscious ecology has become one of the main trends of social life. According to sociological surveys, the ecological consciousness of most Ukrainians is «declarative» because there is a significant gap between ecological values and practically ecologically appropriate activities [1]. At the same time the spread among the youth philosophy of «zero waste» and rules 5R (REFUSE, REDUCE, REUSE, RECYCLE, ROT) are indicative of awareness of a personal responsibility for the preservation and restoration of the environment.

In our opinion ecological education should be considered as a holistic educational process aimed at the formation of a system of ecological knowledge, skills, values and especially an experience of the activities of rational environmental management. At the present stage the ecological competence of the individual is recognized as the criterion and integrative indicator of the quality of ecological education.

In this article we will focus on the methods of forming students' ecological competence. We understand them as the means of interconnected activity of the teacher and the student aimed at the achievement of educational goals teaching, upbringing and development [2, p. 109].

Modern didactics offers a variety of classifications due to different approaches to the selection of their criteria. The most common of them are: the source of transmission and perception of educational information; the nature of cognitive activity; the didactic goals; the levels of cognitive activity of students; the degree of management of educational work and others.

According to the researchers, active learning methods have a great potential because the subject of pedagogical influence is not only the cognitive and emotional spheres, but also the behavior of students [3]. Innovative processes in modern education are characterized by a reorientation to teaching methods that stimulate the independence, non-stereotypical thinking of pupils and students. Therefore, the attention of teachers is directed

\footnotetext{
${ }^{1}$ Sumy National Agrarian University, Ukraine

${ }^{2}$ Sumy State Pedagogical University named after A.S. Makarenko, Ukraine
} 
not only to the transfer of knowledge, but also to the formation and development of the ability to operate them.

Such innovative methods include problem-based learning, brainstorming, project method, business game, case studies as well as the methods of ecological psychopedagogy, including ecological lobbying, ecological empathy, ecological reflection and ecological concern.

Let us dwell on the application of the latest teaching methods of formation students' ecological competence in more details. According to our experience, they are the most effective in determining a personal emotional attitude to ecological problems and contribute to an increasing interest in gaining an experience in solving environmental problems.

We use the method of ecological lobbying in the process of studying the basics of chemical production, which reveals the inappropriateness of using traditional technologies. The teacher or one of the students draws the group's attention to the waste generated by traditional methods and at the same time talks about existing non-waste technologies.

The method of environmental empathy stimulates a projection, that is, the transfer of one's own state to natural objects, experiencing the same states, identifying oneself with an animal or plant, as well as their own emotions and feelings about the state of natural objects.

Mobilizing techniques can be different. For example, the students are encouraged to imagine what a plant that grows near the road and even in a chemical production area (for example, producing of sulfuric acid) feels.

Due to air pollution the stomata is clogged with dust, so the photosynthesis process is weak. Vehicle exhaust, among other harmful substances, also contains dangerous plumbum which inhibits the life of plant cells due to the violation of the redox properties of their cytoplasm. In addition, emissions of sulfur dioxide lead to the occurrence of «acid» rains, which are affected by the plant.

The method of ecological reflection is the psychological and pedagogical organization of self-analysis by the personality of the actions and activities aimed at the environment, taking into account their ecological expediency. This method is important for correcting behavior and creating motivation for improving the technology of an individual interaction with the environment.

We usually invite students to analyze the composition of all non-food waste that accumulates in one day and make an estimate of the transformation of these substances into the environment. Ask them to tell what they are doing with the garbage and how each of them is concerned about reducing household waste.

In organizing an ecological reflection we are also assisted by previously held educational discussions, for example, on such topics as: «Pros and Cons 
of Chemicals for Plant Protection», «Chemical Additives and Food Quality», «Synthetic food: pros and cons», «Positive and negative aspects of nuclear energy» and others. We believe that educational discussions help the students develop independent thinking, skills to express their thoughts reasonably and respect the opinions of others. The discussion of such topics not only deepens students' knowledge, but also raises a particular interest to learning.

The method of ecological concern is aimed at psychological and pedagogical enhancement of ecological activity of the individual, which helps nature and promote natural objects, especially in difficult situations.

This method is used in students' research activities in the form of ecological projects. They can be as educational («modeling ecological problems») - for example, the creation of a model of «acid precipitation» or "greenhouse effect», and practically oriented: «Sanitary and ecological status of the river Psel», «Purification of natural water from $\mathrm{NH}_{4}{ }^{+}$by bentonites».

The students receive guidance on organizing and conducting ecological projects not only from lecturers, but also from online resources (in particular, from http://www.globe.org.uk - «Globe Program» - international research projects for students to study the environment and information exchange).

So, in the process of forming the ecological competence of modern students, along with traditional tools and approaches to learning, which are focused on the assimilation of knowledge and understanding of the nature of biological and chemical processes of nature, less commonly used methods of ecological psychopedagogy are important. Personal involvement, influence on emotions, feelings, understanding of inadequacy of own pragmatic strategies of ecological behavior contribute to rethinking and change of behavior and consciousness of students.

\section{References:}

1. Ekologhichnyj portret ghromadjanyna Ukrajiny Ghromadsjka Synerghija [Environmental portrait of a citizen of Ukraine Public Synergy]. Retrieved from: https://www.civic-synergy.org.ua/analytics/ekologichnyj-portret-gromadyanynaukrayiny/ (accessed 14.03.2020).

2. Lozova, V. I. (ed.) (2006). Lekciji z pedaghoghiky vyshhoji shkoly [Lectures on higher education pedagogy]. Kharkiv : OVS. (in Ukrainian)

3. Zadorozhna, O. M. (2016). Innovacijni metody $v$ ekologhichnij osviti ta vykhovanni studentiv pedaghoghichnykh universytetiv [Innovative methods in environmental education and upbringing of students of pedagogical universities]. Scientific notes of the UDUU ecological laboratory, vol. 19, pp. 94-97. 